\title{
A DINÂMICA GEOMORFOLÓGICA SOB A ÓTICA DO PESCADOR ARTESANAL: ETNOGEOMORFOLOGIA COSTEIRA E ESTUARINA DO LITORAL NORTE DE PERNAMBUCO
}

\author{
Vanessa Martins Lopes \\ Osvaldo Girão?
}

Resumo: A Etnogeomorfologia é um novo campo de investigação, cujo papel é a análise da relação entre seres humanos e relevo, a partir de uma abordagem que considera e valoriza os conhecimentos locais. Tendo como aporte teóricometodológico o estudo de Ribeiro (2012), agora aplicado aos ambientes costeiro e estuarino, o artigo tem como objetivo identificar o conhecimento etnogeomorfológico dos pescadores artesanais, enfatizando os saberes locais acerca dos processos modeladores e formas resultantes nas paisagens costeira e estuarina do litoral do município de Goiana-PE. Enquanto pesquisa de cunho qualitativo, a base da coleta de dados foi a aplicação de entrevistas semi-estruturadas em atividades de campo. Foi identificado um rico acervo de conhecimentos acerca de processos hidrodinâmicos e geomorfológicos modeladores da paisagem costeira e estuarina, sendo tais conhecimentos refletidos em nomenclaturas locais utilizadas pelos pescadores que a partir dos conhecimentos e práticas socioculturais, vem mantendo à longo prazo um necessário equilíbrio ao ambiente costeiro.

Palavras-chave: Etnogeomorfologia, Pescador Artesanal, Geomorfologia Costeira, Goiana- PE.

\section{THE GEOMORPHOLOGICAL DYNAMICS UNDER THE OPTICAL OF THE FISHERMAN: COASTAL AND ESTUARINE ETHNOGEOMORPHOLOGY OF THE NORTH COAST OF PERNAMBUCO}

\begin{abstract}
Ethnogeomorphology is a new field of research, whose role is the analysis of the relationship between humans and relief, based on an approach that considersand values local knowledge. Taking as a theoretical- methodological framework the study by Ribeiro (2012), now applied to estuarine and coastal environments, the article aims to identify the knowledge ethnogeomorphological of artisanal fishermen, emphasizing the local knowledge about the modeling processes and forms resulting in estuarine and coastal landscapes of the coast of the municipality of Goiana- PE. While qualitative research, the basis of data collection was the application of semi-structured interviews in field activities. It was identified a rich collection of knowledge about hydrodynamic and geomorphological processes that shape the estuarine and coastal landscape, being such knowledge reflected in local classifications used by fishermen who, based on socio-cultural knowledge and
\end{abstract}

\footnotetext{
1 Universidade Federal de Pernambuco. wan.martins19@gmail.com

2 Universidade Federal de Pernambuco. osgirao@gmail.com
} 
practices, have maintained in the long term a necessary balance in the coastal environment. .

Keywords: Ethnogeomorphology, Artisanal Fisherman, Coastal Geomorphology, Goiana- PE.

\section{INTRODUÇÃO}

As formas e processos geomorfológicos possuem papel relevante dentro dos sistemas ambientais, e direta e indiretamente, também estão relacionados às sociedades que as ocupam e interagem com suas dinâmicas processuais. Deste modo, essas formas e processos podem interferir nos aspectos sociais, econômicos e culturais, sendo por isso inquestionável a importância de seu estudo, considerando suas influências sobre o meio antrópico.

Em sua evolução cientifica, a Geomorfologia tem inserido gradativamente, sobretudo a partir do século XX, o papel da sociedade na modelagem e dinâmica geomorfológica, ultrapassando as barreiras de uma análise puramente naturalista ao considerar o papel humano na evolução do relevo a partir de sua influência nos processos e, por conseguinte, nas formas deles derivadas. No entanto, as investigações em sua maioria, têm sido direcionadas à ação antrópica e seus impactos negativos sobre os aspectos morfológicos e processuais do relevo.

Estudos sobre os conhecimentos tradicionais, pautados na cultura local, sobre os aspectos geomorfológicos e a utilização desses conhecimentos no uso e manejo da terra ainda são escassos. A escassez desse tipo de análise ocasiona, não raramente, resultados negativos na dinâmica geomorfológica e ambiental, pois em sua maioria as intervenções ocupacionais desconsideram os habitantes locais e o seu longo e consolidado conhecimento sobre a dinâmica da paisagem local.

Neste sentido, a Etnogeomorfologia como um novo campo de investigação, tem como foco a análise da relação entre os seres humanos e o relevo, quanto as suas formas e processos atuantes a partir de uma abordagem que considera e valoriza os conhecimentos locais oriundos dessa inter-relação.

Tendo como principal aporte teórico-metodológico o estudo de Ribeiro (2012), que desenvolveu tal abordagem em região semiárida do estado do Ceará, o artigo em questão tem como objetivo identificar o conhecimento (etno) geomorfológico dos pescadores artesanais do litoral norte de Pernambuco, enfatizando os saberes locais acerca dos processos modeladores da paisagem costeira e estuarina do litoral do município de Goiana.

\section{A ETNOGEOMORFOLOGIA}

Gregory (2006) destaca em seu estudo sobre a influência humana na mudança de canais fluviais, que a cultura não é considerada pelos geomorfólogos, embora os benefícios de uma abordagem pautada também numa perspectiva cultural devam surgir a partir de uma maior compreensão de como a percepção do papel humano muda os canais fluviais (e também outros sistemas ambientais) ao longo do espaço e do tempo.

Neste âmbito, a Etnogeomorfologia emerge como uma abordagem que veio para incluir e compreender o papel do ser humano como um agente cultural ativo, extremamente importante dentro do sistema geomorfológico. Ela irá resgatar os valores das culturas locais sobre o relevo, pautando-se sob a ótica do entendimento 
e práticas de uso e manejo que essas comunidades exercem sobre a paisagem geomorfológica de que fazem parte, dando grande ênfase também aos processos geomórficos atuantes nas mesmas (RIBEIRO, 2012).

Sinteticamente, a Etnogeomorfologia pode ser definida como uma ciência hibrida firmada na interface entre ciências naturais e sociais, que estuda o conhecimento que uma comunidade tem acerca das formas e processos geomorfológicos, levando em consideração os saberes sobre a natureza e os valores da cultura e tradição locais. Pode ser considerada como uma ciência coirmã da Etnopedologia, sendo ambas intrinsecamente relacionadas à Etnoecologia (BARRERA- BASSOLS; ZINCK, 2003; RIBEIRO, 2012).

A Etnoecologia trata-se do estudo interdisciplinar que visa compreender como a natureza é percebida pelos seres humanos através de uma tela de crenças e conhecimentos, e como, por meio de seus significados e representações simbólicas, os humanos usam e/ou gerenciam as paisagens e recursos naturais. Já a Etnopedologia, visa documentar e compreender as abordagens locais para a percepção, classificação, avaliação, uso e gestão do solo (BARRERA- BASSOLS; TOLEDO, 2005; BARRERA- BASSOLS; ZINCK, 2003).

As taxonomias e classificações geomorfológicas que as comunidades locais possuem para as formas e processos morfoesculturadores são elementos essenciais para o estudo etnogeomorfológico, já que revelam a experienciação do indivíduo com a paisagem geomorfológica. A respeito dessas classificações, deve-se considerar que:

A literatura abunda em exemplos sobre os termos utilizados pelos povos tradicionais para distinguir e nomear grandes estruturas geomorfológicas. Praticamente toda cultura possui termos para designar os principais acidentes de seu espaço terrestre (planícies, vales, declives, montanhas, picos) ou aquáticos (DUVALL, 2008 apud TOLEDO; BARRERA-BASSOLS, 2009, p. 37).

A investigação etnogeomorfológica pode ser usada para fornecer um quadro para o diálogo, que pode situar diferentes saberes em efetivo, mas que certamente nem sempre são consensuais. Além disso, ela possibilita vias de comunicação que promovem e reforçam as sinergias entre a geografia humana e a geografia física, colaborando para reconhecer paisagens como entidades simultaneamente geomorfológicas e culturais (WILCOCK et al., 2013).

Cabral (2000) defende que as paisagens, assim como espaços e lugares, na medida em que são experienciadas diretamente como atributos do mundo vivido, constituem as bases fenomenológicas da realidade geográfica e representam sentido dos nossos envolvimentos com o mundo. Do mesmo modo, Wilcock et al. (2013) ressaltam que a Etnogeomorfologia se baseia numa conexão: conexão entre as paisagens físicas e os seres humanos. Estas paisagens biofísicas/culturais são inscritas pela sobreposição de histórias, histórias que representam experiências vividas e implicam numa "tempestade perfeita" de relações entre paisagens e aqueles que a habitam e estão contidos dentro dela. Em tese, as paisagens são vistas como entidades (vivas) dinâmicas e sensíveis que necessitam de uma voz para si próprias.

Wilcock (2011) relembra que a abordagem ocidental dominante tem enquadrando os povos indígenas (e também outros povos tradicionais) em ideais românticos, dentro de uma perspectiva de natureza intocada, tal como destaca Diegues (1996). Esta autora afirma que quando os povos indígenas não atendem a tais expectativas dentro deste idealismo romântico, pela aparência e/ou crenças 
(porque foram "contaminados pela modernidade"), são fisicamente excluídos do processo de decisão na gestão de recursos naturais.

No entanto, como afirmam Santos (2006) e Cuche (1999 apud SOUTO, 2004) a discussão de cultura remete a noção de processo já que os sistemas culturais estão sendo remodelados constantemente, sendo o dinamismo uma característica intrínseca da cultura. Assim sendo, as culturas não são estáticas e também não se encontram isoladas das demais, sofrendo interferências externas, fato que não extingue a essência cultural do grupo em questão, que tem seus traços característicos preservados (SALDANHA, 2005).

A importância e riqueza do conhecimento etnogeomorfológico se revela a partir das histórias contadas, da explicação da dinâmica natural e da classificação ambiental e geomorfológica local, os quais são dotados de coerência e detalhes que são construídos através da observação e manejo do ambiente.

No que concerne às ações de planejamento e gestão ambiental e territorial, percebe-se um necessário diálogo entre o conhecimento acadêmico e os saberes locais das populações inseridas em determinadas espacialidades. A esse respeito, Posey (1984), Sillitoe (1998) e Morin-Labatut e Akhtar (1992) ressaltam que os saberes e técnicas tradicionais complementam o conhecimento científico em pesquisas básicas sobre a avaliação de impactos ambientais, manejo de recursos e desenvolvimento sustentável. O conhecimento local pode ser usado como um estágio preliminar da investigação ecológica e pode subsidiar planos de manejo visando uma exploração sustentável do ambiente (ALVES; NISHIDA, 2002).

Moretz-Sohn et al. (2013) ao falar sobre o papel dos pescadores artesanais na implementação de áreas marinhas protegidas, destaca que a presença de populações tradicionais, suas atividades econômicas e seus conhecimentos da natureza são importantes para o planejamento de ações voltadas para espaços já ocupados, ou a serem ocupados. Segundo eles, as diretrizes e as políticas para as unidades de conservação carecem de um debate com estas populações, como os pescadores artesanais, por exemplo, que são partícipes na vida local e podem dar uma importante contribuição para o gerenciamento destes ambientes, incluindo a implementação de unidades de conservação através do compartilhamento das suas experiências sobre a estrutura e o funcionamento dos ambientes costeiros.

\section{ETNOGEOMORFOLOGIA DE AMBIENTES COSTEIROS E ESTUARINOS}

O pescador detém meios intelectuais para o desenvolvimento de suas atividades, e a identificação dos lugares mais produtivos é um requisito básico para o exercício da pesca. A distribuição dos recursos pesqueiros no espaço marinho/estuarino/fluvial não é fruto do destino e produto da casualidade, mas está associada a fatores como o tipo de substrato do fundo, a temperatura, a profundidade, correntes e época do ano (ALLUT, 2000). Podemos inferir que se o pescador sabe identificar os locais que se concentram os recursos pesqueiros, logicamente ele possui conhecimento sobre as principais características do ambiente biofísico que influencia tais recursos.

O relevo marinho condiciona formas distintas de pescaria e a configuração de sua geologia define quais são os locais apropriados para a utilização de cada uma das artes de pesca (SALDANHA, 2005). A esse respeito, Garcez (2007), em seu trabalho sobre a caracterização da pesca artesanal autônoma no estado do Rio de Janeiro, relata os conhecimentos de pescadores artesanais sobre a relação entre os 
tipos de fundo marinho e as espécies encontradas em cada um, bem como sobre a distância percorrida e a profundidade dos pontos de pesca.

Os pescadores possuem conhecimento sobre a história natural, a identificação dos recursos pesqueiros e espécies existentes, a origem dos problemas referentes à utilização dos recursos naturais da região e consequências para a pesca, servindo como aporte aos trabalhos científicos que subsidiam a gestão dos ecossistemas costeiros (SILVA, 2006).

Nas comunidades pesqueiras litorâneas onde predomina a pesca artesanal observa-se uma relação entre o funcional e o cultural, onde o ambiente natural tende a determinar o ritmo de vida. A cultura tradicional desses grupos se fundamenta, sobretudo, nas especificidades da natureza, nos seus ciclos e na sua imprevisibilidade. A relação homem-natureza evidencia a noção tridimensional do pescador acerca do espaço que abarca os distintos domínios de vida: mar, terra e céu, dotados de significado próprio (SALDANHA, 2005; SILVA, 2006).

Os conhecimentos do mar abrangem, dentre outros elementos, os ecossistemas marinhos, as marés, as correntes, a temperatura e a salinidade. $\mathrm{Na}$ terra ocorre a preparação para a pescaria como o trabalho de tecer das redes e a organização social da pesca, por exemplo. Já o céu demanda conhecimentos sobre as condições atmosféricas, ventos, chuvas, secas e influência de astros como a Lua (SALDANHA, 2005; SILVA, 2006).

No entanto, a atividade pesqueira é influenciada por uma série de condicionantes ambientais e sociais tais como: os aspectos geográficos da região, as variações sazonais, as condições climáticas, as flutuações naturais das populações explotadas, a competição por espaço e uso dos recursos com demais setores produtivos, oscilações nos padrões de consumo e encaminhamentos, direcionamentos e resoluções das políticas e/ou administração públicas e propostas de manejo (quando existentes) (GARCEZ, 2007).

Assim, reitera-se a importância e a riqueza de conhecimentos dos pescadores artesanais, não só brasileiros, mas de todo o mundo, destacando-se os saberes de caráter (etno) geomorfológicos. No entanto, não podemos esquecer que os saberes locais são multifacetados. A riqueza cultural dos povos dos rios e dos mares merece expandir-se para além do reflexo das águas serenas dos rios ou agitadas do mar, e solidificar-se também em terra firme, contribuindo para uma gestão mais participativa no que se trata de ações voltadas ao uso e ocupação de áreas costeiras.

\section{O CONTEXTO GEOAMBIENTAL DO LITORAL DE GOIANA- PE}

O presente trabalho realizou-se nos setores costeiro e estuarino do município de Goiana, Litoral Norte de Pernambuco. O mesmo encontra-se na porção limítrofe com o estado da Paraíba, sendo o limite natural de demarcação fronteiriça o rio Goiana. As áreas de estudos, especificamente, foram as comunidades de Atapuz, São Lourenço, Carne de Vaca e Barra de Catuama (Figura 01). As duas primeiras vinculadas ao ambiente estuarino, enquanto as duas últimas ao ambiente costeiro. 
Figura 1: Localização do município de Goiana- PE e áreas de estudo.

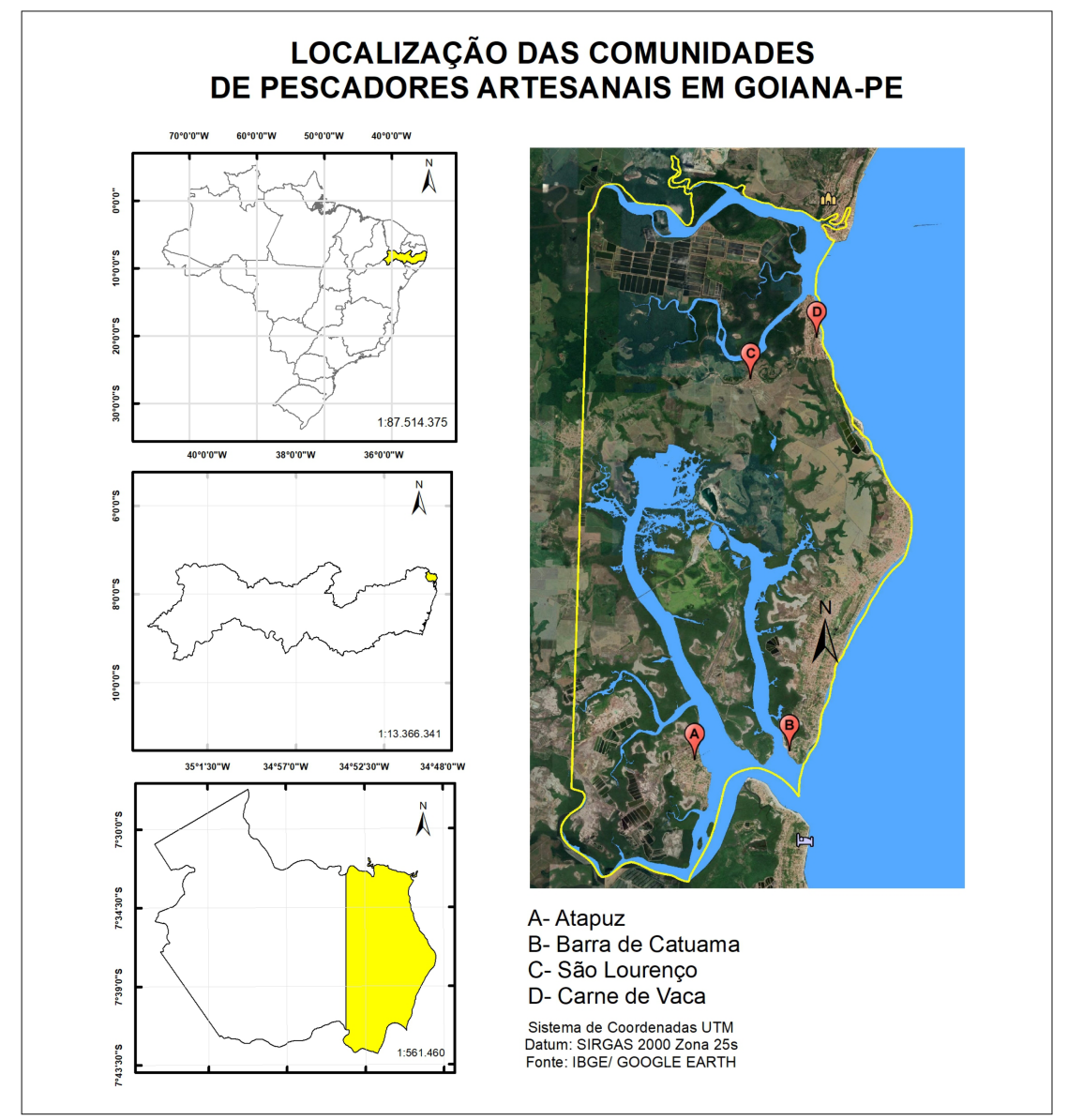

Fonte: Autores.

A área faz parte da Bacia Sedimentar da Paraíba que abrange uma faixa sedimentar costeira de 130 quilômetros entre Pernambuco e Paraíba, sendo esta limitada ao sul pelo Lineamento Pernambuco, nas proximidades de Recife-PE, e ao norte pela Falha de Mamanguape, localizada na porção setentrional de João Pessoa-PB. A área emersa da bacia apresenta uma espessura de depósitos sedimentares em torno de 300 metros na linha de costa, não havendo grabens profundos, como é o caso da Bacia Pernambuco. Apresenta-se dividida em três subbacias: Olinda, Alhandra e Miriri, separadas, respectivamente, pelas falhas de Goiana e Itabaiana- Pilar. (ALCANTARA; TORRES; LIMA, 2014; BARBOSA; LIMA FILHO, 2005). A área de estudo está compreendida na Sub-bacia Olinda.

Os depósitos quaternários são constituídos por sedimentos terrígenos (areias, argilas e conglomerados), e correspondem a sequências aluvionares ou elúviocoluvionares (ALCANTARA; TORRES; LIMA, 2014). A CPRH (2003) enumerou os sedimentos quaternários de origem marinha, fluvial ou mista para o Litoral Norte de Pernambuco, os quais compreendem: depósitos aluviais ou aluviões, depósitos de brejo e pântanos, depósitos de mangue, terraços marinhos pleistocênicos e 
holocênicos, praias, recifes de arenito (beachrocks), recifes orgânicos e flechas litorâneas.

Ao longo do litoral pernambucano estão presentes quinze estuários, destes, apenas dois estão contemplados na área de estudo: o estuário Goiana-Megaó e o estuário de Itapessoca. O primeiro é do tipo "Planície Costeira", tendo sua formação associada à transgressão marinha no Holoceno, onde o processo de inundação foi mais acentuado que o de sedimentação, tornando a topografia atual dos estuários semelhantes ao vale do rio. O segundo é do tipo "Ria", de origem tectônica, sendo formado pela elevação de blocos onde se localizavam o vale interior dos rios, constituindo assim a ria, uma morfologia irregular (formação de ilha), onde seus tributários drenam regiões adjacentes (SILVA et al., 2011).

No que concerne aos aspectos oceanográficos, a costa pernambucana é do tipo mesomaré, sendo dominada por ondas sob influência da ação de ventos brandos, denominados alísios, de direção E-SE entre abril e setembro, e de maior intensidade nos meses de agosto e setembro, e de direção N-NE no período de outubro a março, estes de menor intensidade durante a primavera-verão. As marés são semidiurnas, com valores de altura variando de 2,4 metros para sizígia máxima e 0,7 metros para a maré de quadratura (ASSIS, 2007).

Segundo Lira (1987 apud LIRA et al., 2010), o sistema de circulação costeira no litoral de Pernambuco é regulado pela direção e pela intensidade dos ventos, deste modo, os ventos oriundos de sudeste, mais intensos e mais frequentes, impõem correntes costeiras no sentido de sul-norte, já os ventos do quadrante nordeste, mais fracos e menos frequentes, invertem a tendência das correntes que passam a seguir para sul.

O litoral de Goiana possui como cobertura vegetal alguns remanescentes de Mata Atlântica, que ocorrem geralmente nas encostas de tabuleiros e morros de alta declividade (Figura 2), e em menor proporção nas colinas e modelados suaves da porção oriental da área. Nos setores que sofrem a influência das oscilações das marés, se desenvolvem os manguezais, que vem sido degradados pela ocupação urbana, pela pesca predatória, pela deposição de resíduos sólidos e, atualmente também, pelo avanço dos empreendimentos de carcinicultura. Em Goiana encontrase ainda a Reserva Extrativista Acaú-Goiana, que visa a proteção e conservação dos recursos naturais renováveis a fim de garantir o seu uso sustentável $(\mathrm{CPRH}$, 2003).

A aquicultura é muito nítida em Goiana como se observa na Figura 2. Segundo a CPRH (2003), o município contempla a aquicultura artesanal (peixe, camarão e ostra), a qual é realizada por meio de técnicas rudimentares com produção reduzida; e a aquicultura com tecnologia avançada e produção em larga escala, compreendida pela carcinicultura.

No que se refere à fauna, segundo a CPRH (2003) o Litoral Norte de Pernambuco possui aproximadamente duzentas espécies animais, incluindo mamíferos, aves, répteis e anfíbios. Dentre as espécies, destacamos àquelas relacionadas aos ambientes estuarino e marinho e que são compostas por: moluscos como marisco-pedra (Anomalocardia brasiliana) e o sururu (Mytella falcata); crustáceos, como camarão (Panacus subtilis), siri (Callicnetes spp) e caranguejo-uçá (Ucides cordatus); e peixes, como sardinha (Opisthonema oglium), tainha (Mugil curema) e manjuba (Anchoviella lepidentostole). A fauna associada ao sistema estuarino e também marinho desempenha importante papel na segurança alimentar e sobrevivência socioeconômica das comunidades da região que dependem diretamente destes recursos pesqueiros. 
Figura 2: Mapa de uso e ocupação das terras do litoral de Goiana- PE.

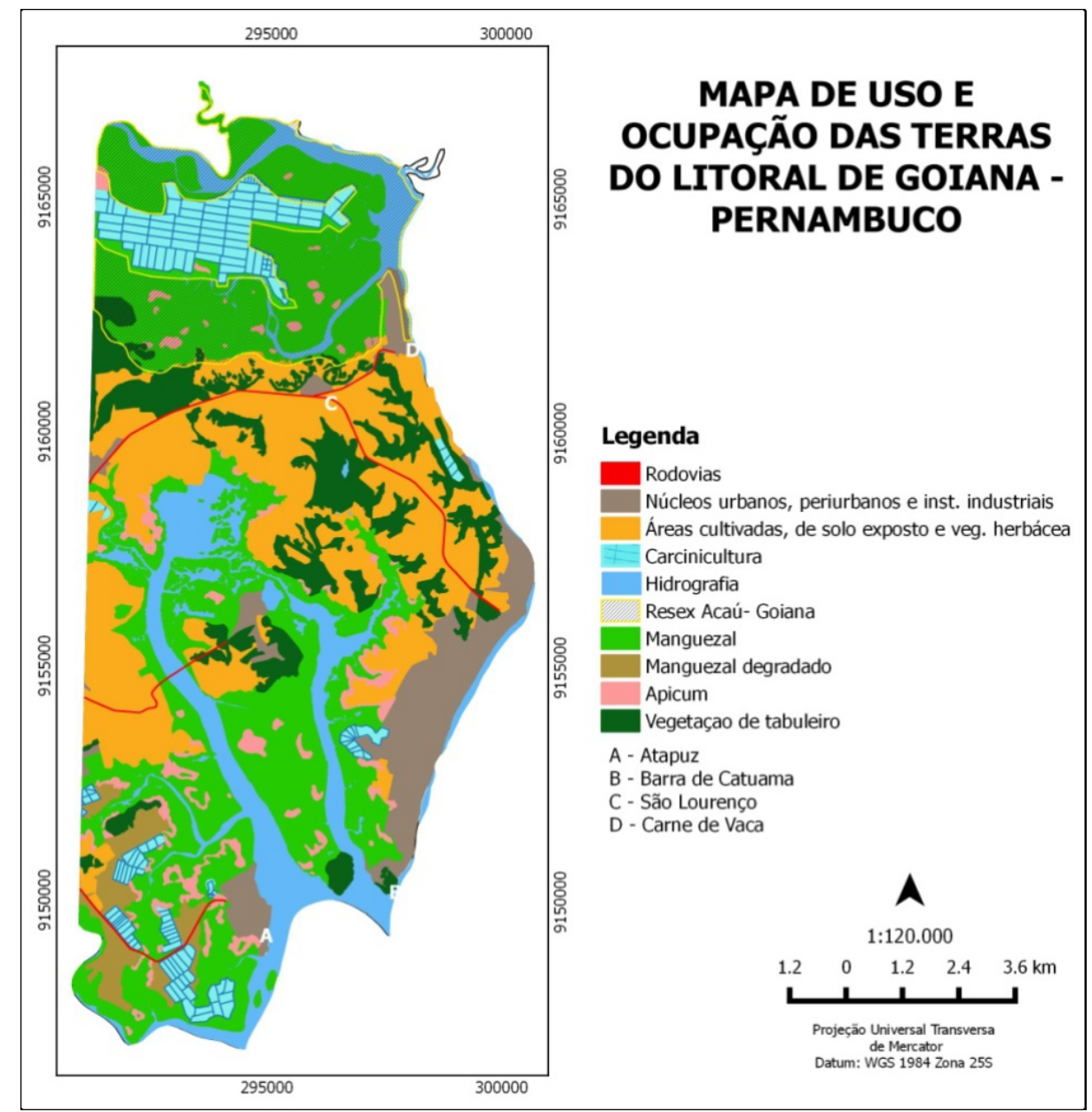

Fonte: ZAPE (2001), adaptado pelos autores.

\section{O PESCADOR DO LITORAL NORTE PERNAMBUCANO}

Pode-se considerar pescador profissional artesanal aquele que, com meios de produção próprios, exerce sua atividade de forma autônoma, individualmente ou em regime de economia familiar, ou com auxílio eventual de parceiros, sem vínculo empregatício (SEAP, 2004).

Segundo Garcez (2007) a literatura sobre o tema mostra que pescadores artesanais atuam geralmente próximo à costa e à profundidades relativamente reduzidas, fato condizente com a realidade aqui observada, já que no litoral norte pernambucano segundo Lira et al. (2010), $71 \%$ dos pescadores pescam no estuário/manguezal, $14,3 \%$ no mar "de dentro" e 7,2 \% no mar "de fora".

A pesca artesanal representa a maior parcela da produção pesqueira de Pernambuco, e é caracterizada pelo trabalho familiar e comunitário, a partir do emprego de técnicas e tecnologias tradicionais (Figura 3), com ou sem o uso de embarcações, e variadas artes de pesca, cujo objetivo final é utilizar o pescado para fins comerciais e/ou de subsistência. O município de Goiana, no ano de 2010, encontrava-se como o segundo maior produtor de pescado do Estado de Pernambuco (LIRA et al., 2010).

Lessa et al. (2006) destaca que os pescadores artesanais vivem em situação socioeconômica precária, possuindo de maneira geral baixa escolaridade, 
dificuldade de acesso a linhas de financiamento e problemas com infraestrutura de armazenamento e comercialização do pescado. Tais problemas foram constatados em campo em 2016, acrescentando-se ainda a dificuldade de acesso a seguridade social, como a aposentadoria.

Figura 3: Pescadores artesanais utilizando pequena embarcação na comunidade de Barra de Catuama, Goiana- PE.

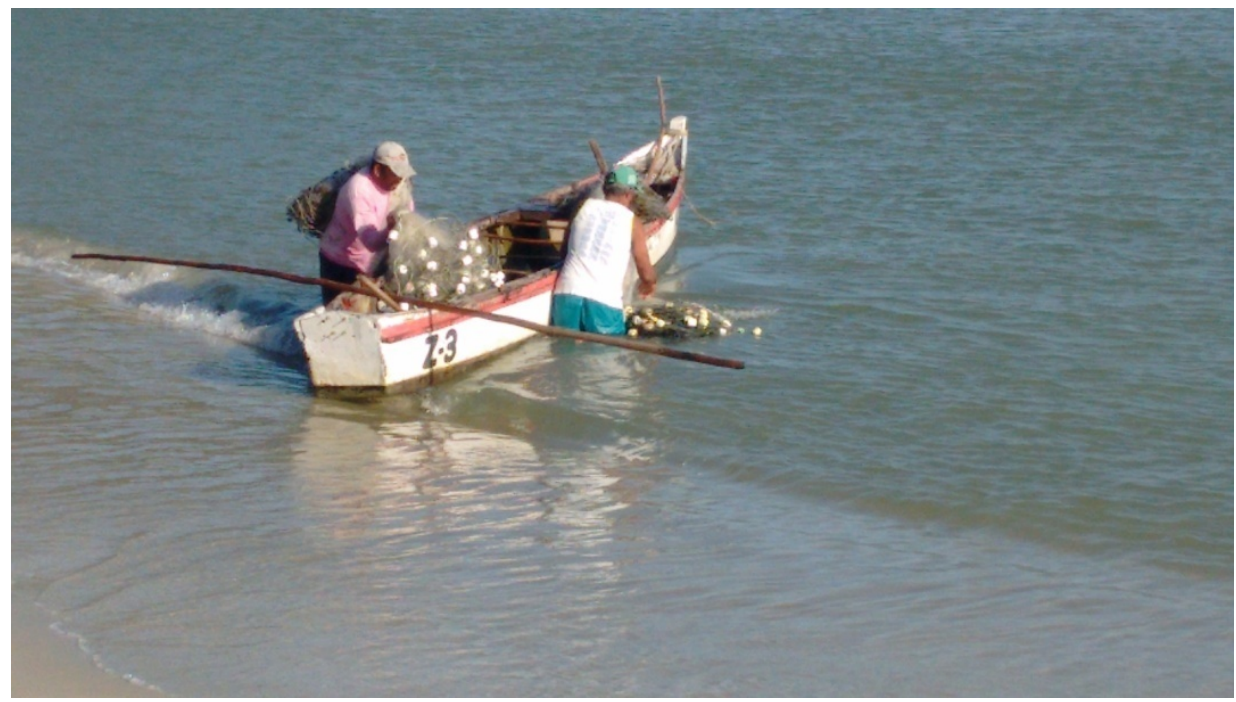

Fonte: Autores. Trabalho de campo realizado em 01/07/2016.

\section{METODOLOGIA}

O presente trabalho possui como base os aportes teórico-metodológicos de Ribeiro (2012), a qual propõe o estudo geomorfológico sob um novo olhar, pautado na perspectiva etnocientífica. Os procedimentos metodológicos que possibilitaram o desenvolvimento dessa pesquisa consistiram no levantamento de materiais bibliográficos, produção da base cartográfica, atividades de campo para reconhecimento das áreas de estudo, aplicação de entrevistas semiestruturadas e, por fim, a análise das últimas.

A forma de abordagem foi qualitativa, quando o pesquisador procura, na sua elaboração, seguir a tradição compreensiva ou interpretativa. É importante a sua imersão no contexto de interpretar e interagir com o objeto estudado, além da adoção de uma postura teórico-metodológica para decifrar os fenômenos (PÊSSOA, 2012).

A aplicação das entrevistas foi realizada nos meses de junho e julho de 2016, sendo entrevistado um total de 39 pessoas, sendo 9 mulheres e 30 homens, com idades entre 22 e 81 anos. Em Atapuz foram entrevistadas 9 pessoas, em Barra de Catuama 12, em Carne de Vaca 9 e em São Lourenço 9 pessoas.

A fim de garantir o anonimato dos pescadores entrevistados, optamos por identificá-los através de siglas juntamente com números, diferenciados em cada comunidade. As siglas utilizadas estão relacionadas aos nomes de cada comunidade e foram as seguintes: Pescador de Atapuz- PA, Pescador de Barra de CatuamaPBC, Pescador de Carne de Vaca-PCV e Pescador de São Lourenço- PSL. 


\section{OS PROCESSOS HIDRODINÂMICOS NA VISÃO DO PESCADOR ARTESANAL PERNAMBUCANO}

Nas atividades de campo e entrevistas realizadas constatou-se que o pescador consegue identificar a atuação das marés e outros processos hidrodinâmicos na modelagem da paisagem costeira local. Dentre os processos observados, as marés e suas correntes recebem maior destaque, e são reconhecidas como fator que influencia diretamente a dinâmica erosiva e deposicional das áreas costeiras, além de, logicamente, atuar nas condições da própria atividade pesqueira. Além da dinâmica das marés, as ondas, as correntes marítimas e a ação dos ventos também são citados como fatores que modelam a paisagem costeira e mesmo estuarina.

Como dito, dentre os fatores condicionantes da dinâmica geomorfológica e hidrodinâmica local, se destaca o regime das marés. Silva e Garcia (2013) em trabalho com pescadores de Lucena-PB, ressaltam que as marés, o vento e a Lua determinam as boas condições para a pesca, no entanto, a maré constitui-se o elemento de maior peso como condicionante para a pesca.

Deste modo, o ritmo de vida do pescador é determinado pela dinâmica das marés, conforme observado também por Souto (2004) ao estudar comunidades de pescadores baianos. O autor destaca que as marés ditam os horários de saída e chegada, além da escolha dos sítios e das estratégias empregadas na pescaria.

As marés semidiurnas passam um período de cerca de seis horas de fluxo (para alcançar a preamar), e seis horas de refluxo (para alcançar a baixa-mar), de modo que em um dia lunar ( $24 \mathrm{~h} 50 \mathrm{~m} 28 \mathrm{~s})$ há duas preamares e duas baixa-mares. De modo geral, é justamente por causa da diferença de tempo entre o dia solar (24h) e o dia lunar que as marés possuem uma variação de aproximadamente 50 minutos de um dia para o outro.

As oscilações das marés são provocadas pelo movimento de translação da Lua em torno da Terra, em que ocorrem situações que a Terra, a Lua e o Sol estão alinhados ou formam um ângulo reto. Quanto mais alinhados estiverem esses astros, maior será o efeito na massa marítima, causando marés de maior amplitude, os quais correspondem às marés vivas ou de sizígia, que ocorrem durante as fases de Lua Nova e Cheia. Já quando estão em quadratura formando um ângulo reto de $90^{\circ}$, essa influência diminui e as diferenças de nível entre as marés alta e baixa são menores; são as marés de quadratura que ocorrem nas fases Quarto Crescente e Minguante (APRH, 2007).

As oscilações diárias das marés através do processo de fluxo e refluxo são classificadas localmente pelos pescadores de "maré de enchente", quando o nível da maré está subindo e "maré de vazante" quando este nível está descendo. Denominam de "maré alta" quando está em seu nível máximo, ou seja, na preamar, e "maré baixa" em seu nível mínimo, ou seja, baixa-mar.

Além das variações diárias, as marés possuem variações mensais, relacionadas aos astros, como a Lua e o Sol, que irão definir os diferentes tipos de marés existentes identificados pelos pescadores, os quais são bastante influentes na prática de pesca.

Desta forma, são identificadas as seguintes marés que variam em um ciclo mensal na seguinte sequência, conforme denominação local: "maré grande", "maré de quebramento", "maré morta", "maré cabeça de água morta" e "maré de lançamento". 
A maré de sizígia é denominada de "maré grande" e por vezes também de "maré alta", sendo àquela que ocorre após as fases de "lançamento", tratando-se do ápice de nível mais alto da maré dentro de um ciclo mensal, o qual ocorre nas "noites de Lua" (Lua Cheia) ou "noite de escuro" (Lua Nova). Os pescadores destacam que é uma maré "secadeira", referindo-se à amplitude da mesma quando está na fase de preamar, pois "alaga o mangue todo", mas que, quando na fase baixa-mar tem seu nível diminuído, levando as "croas" 3 a ficarem emersas. Ainda afirmam que a maré grande "corre" muito, ou seja, possui fortes ondas de correntes de maré, sendo responsável pela erosão da costa, já que escava e retira sedimentos.

Os períodos de transição entre as marés de sizígia e de quadratura são denominados de "maré de quebramento" e "maré de lançamento". A "maré de quebramento" é aquela que ocorre no intervalo de tempo entre as fases Lua CheiaQuarto Minguante e Lua Nova- Quarto Crescente, ou seja, entre as marés "grandes" e "cabeça de água morta". Os pescadores relatam que é quando ela está baixando o seu nível gradativamente, passando seis dias diminuindo até alcançar a fase "cabeça de água morta". Destacam que é uma "maré fraca" (com pouca atuação das correntes de maré), e quando o pescador pensa que ela está secando, ela já está enchendo novamente (pequenas amplitudes).

A maré de quadratura é denominada de "maré morta", "maré pequena" ou "maré seca" e corresponde ao período das menores amplitudes entre as marés. Ocorre nas fases de Lua Quarto Crescente e Quarto Minguante, e caracteriza-se por uma baixa preamar e uma alta baixa-mar. Os pescadores afirmam que a "maré morta" "não cresce" (não alcança altos níveis), já que é uma "maré mansa", "fraca" e "parada", ou seja, ela é mais calma porque não tem "carreira d'água" e "correnteza" (correntes de maré). O PSL5 (67 anos) destaca que esse tipo de maré "só bota no nível do bardo (margens)", ou seja, ela só atinge o leito menor do rio, por ser a maré de menor amplitude.

"Cabeça de água morta" é o termo utilizado para denominar a maré que ocorre nos últimos dias da "maré morta", ocorrendo quando a lua começa a mudar, passando para a fase de Lua Cheia ou Nova. Segundo o PA1 (28 anos) ela "amanhece o dia parada e depois vai lançar". Os pescadores afirmam que é o nível mais baixo que a maré pode ficar, e a partir dela se inicia um novo ciclo de "lançamento".

Por fim, a "maré de lançamento" é o intervalo compreendido entre as fases lunares Quarto Minguante- Lua Nova ou Quarto Crescente-Lua Cheia. Nessa fase a maré vai "crescendo" gradativamente dia após dia, ocorrendo logo após a maré "cabeça de água morta" através do primeiro lançamento, segundo lançamento, até alcançar aproximadamente o sexto lançamento seguido da fase de topo da maré alta: a "maré grande", fechando assim o ciclo mensal. Destacam que "onde ela botou, ela já vai botar mais para cima" (PCV6, 41 anos), fazendo referência ao seu crescimento gradativo. Segundo eles ela é muito "corredeira", ou seja, possui fortes correntes de maré, o que dificulta a pesca.

A síntese da dinâmica das marés em um ciclo mensal, comandada pelas fases lunares estão ilustradas na Figura 4. Foi identificada também nomenclaturas para as marés de acordo com a sua relação com as fases da Lua, as quais não se encontram explicitadas na referida figura. Essa classificação ocorre da seguinte

\footnotetext{
${ }^{3} \mathrm{As}$ "croas" se referem às barras arenosas, estruturas morfológicas muito notáveis em ambientes praiais, situadas na zona submersa próxima da costa e importantes no que se trata do volume de sedimentos armazenados (BARBOSA, 2007; CALLIARI et al., 2003). Cardoso (2001) e Souto (2004) em trabalho com pescadores artesanais encontraram nomenclaturas similares para essas formas.
} 
maneira: na "noite" ou "dia de Lua" (Lua Cheia) ocorre a "maré de Lua" (maré grande/sizígia); na "noite de escuro" (Lua Nova) ocorre a "maré de escuro" (maré grande/sizígia) e no "dia de quarto" (Quarto Crescente e Minguante) ocorre a "maré de quarto" (maré morta/quadratura).

Figura 4: Relação entre as fases lunares e o regime das marés.

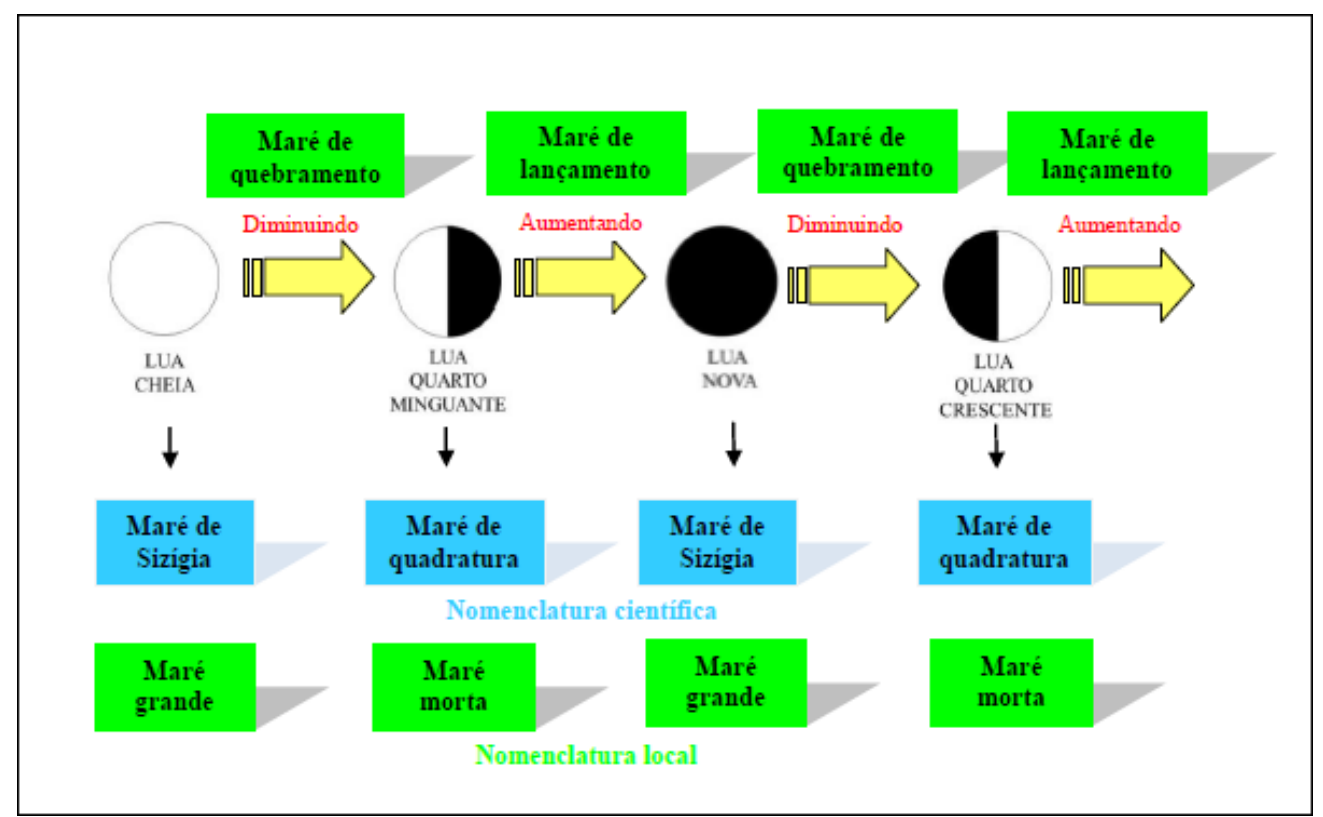

Fonte: Autores.

As marés citadas acima, na verdade, são as mesmas ilustradas na Figura 4 para cada fase lunar, no entanto a nomenclatura é distinta porque a associação para classificar cada maré foi feita com a Lua, e não com as suas características físicas. De maneira geral, no que se trata da classificação do regime das marés, nomenclaturas similares foram encontradas nos trabalhos de Alves e Nishida (2002), Ramalho (2004), Silva e Garcia (2013) e Souto (2004).

As órbitas da Terra e da Lua não são circulares, mas elípticas, ou seja, as distâncias entre os astros não são fixas. O plano onde se encontra a órbita da Terra não coincide com o plano do Equador, assim, quando o astro que provoca a maré, seja ele o Sol ou a Lua, está sobre o Equador ou próximo dele, as marés tendem a ter uma maior amplitude. No caso do Sol esse fenômeno ocorre nos equinócios. No hemisfério sul o equinócio de outono ocorre em geral no dia 21 de março, já o de primavera ocorre por volta do dia 22 ou 23 de setembro. As marés vivas que ocorrem próximo dos equinócios chamam-se "marés vivas equinociais". De fato, as marés de maior amplitude de cada ano tendem a ocorrer próximo desse período, mais mês, menos mês (INSTITUTO HIDROGRÁFICO, 2016).

O resultado desse fenômeno nas variações das marés é percebido pelos pescadores que denominam de "maré de carnaval" ou "maré de março" (equinócio de outono) e "maré de agosto" (equinócio de primavera). Afirmam que são as marés mais altas observadas, e que esse período é o "mês de ressaca", quando o mar fica muito "brabo" geralmente por causa dos ventos intensos, sobretudo no mês de agosto, mês reconhecido como de maior atuação dos ventos no litoral oriental nordestino.

Sobre outros processos hidrodinâmicos modeladores da paisagem costeira, os pescadores reconhecem as correntes de maré que se tratam da movimentação 
horizontal alternante da água em função da subida ou da descida das marés. A periodicidade, bem como a orientação dessas correntes, depende dos regimes das marés e se elas atingem seus máximos de velocidade, nas marés de enchente e de vazante (CEM/UFPR, 2016; MARINS, 2010). São localmente denominadas de "correnteza" ou "carreira d'água", sendo descritas como a "velocidade da maré" e a correnteza que flui do mar para o rio. Afirmam que elas se sobressaem na maré "grande", quando a maré "corre mais", corroborando assim com Bird (2008) que expõe que as correntes de maré são mais fortes nas marés vivas, já que um maior volume de água é movido.

Os pescadores demonstram conhecer o papel geomorfológico das correntes de maré na modelagem da paisagem costeira através do transporte sedimentar, como é notável na fala do PBC2 (29 anos), ao afirmar que: "as carreira d'água na costa é mais constante e traz muita areia". No entanto, apesar do termo "carreira d'água" se referir em maior proporção às correntes de maré, na comunidade São Lourenço, provavelmente por ser uma área estuarina com terraços fluviais e de topografia mais íngreme, portanto totalmente distinta das demais comunidades, os pescadores reconhecem as "carreiras d'água com sentido diferente das demais comunidades, entendendo-as como os fluxos pluviais que causam um grande volume de água fluindo do rio para o mar.

O processo de rebentação de ondas é tratado como "quebramento" de ondas, ocorrendo porque "o mar quebra quando a onda é grande e o mar sai embolando" (PBC12, 22 anos). Uma das formas responsáveis pelo quebramento das ondas são os cabeços ${ }^{4}$.

Segundo um pescador, as áreas de canais $^{5}$, mais profundas, influem sobre as características das ondas, pois "quanto mais tem um canal, as ondas ficam mais fluiosa, mais braba" (PCV4, 44 anos). Já o termo "ressaca do mar", é utilizado para se referir ao mar quando ele está agitado, sendo que os pescadores definem as ondas grandes e perigosas de "boiadeira" e "ondas de temporal".

O PCV4 (44 anos) relata que há uma área a qual é denominada de "mar cavado", onde as ondas sobem e descem, nesse local situado ainda no mar de dentro, trafegam os barcos motorizados. A definição local do pescador condiz com a do Portogente (2016), a qual define o mar cavado como um "mar de ondas grandes, altas e espaços fundos entre elas".

O termo "corrente marítima" é identificado na fala da pescadora PSL6 (36 anos) que afirma que "o que acontece em Ponta de Pedras dependendo da corrente marítima vai atingir aqui". Entende-se que as correntes a qual a pescadora se refere, são as correntes longitudinais, que se deslocam paralela ou subparalelamente junto à costa (WINGE et al., 2001), e que são responsáveis em grande parte pela manutenção do equilíbrio dos ambientes costeiros já que se destacam no transporte sedimentar, podendo causar mudanças no balanço sedimentar a sotamar em virtude de alterações na dinâmica ambiental a barlamar.

Outro processo descrito pelos pescadores é o "repuxo", que sofre influência da ação do vento, e influencia os processos de erosão da costa. Definem esse processo como típicos de áreas de "mar aberto", que "ocorre mais onde tem ondas"

\footnotetext{
${ }^{4}$ Segundo Marins (2010) essas são feições submersas de formato arredondado presente no assoalho oceânico. Pedrosa (2007) em um trabalho de percepção ecológica com pescadores artesanais do litoral sul pernambucano faz referências a fundos rochosos correspondentes aos "cabeços" de calcário, Almeida (2010) também identifica o termo em comunidades de pescadores cearenses. Em Goiana- PE os pescadores definem como uma "área seca" de pedra, sendo menor que a "laje" (aqui entendido como recifes/beachrocks).

5 O canal trata-se de uma "zona deprimida do perfil de praia submarina, com disposição mais ou menos paralela à praia emersa, normalmente associada a uma barra submarina" (APRH, 2007). Souto (2004) também identifica o termo em comunidades de pescadores artesanais baianos.
} 
(PCV6, 41 anos). Segundo as descrições o repuxo seria um processo conhecido como "refluxo" que se refere à movimentação da água, após o espraio, na direção do oceano (APRH, 2007).

Ao contrário dessas correntes que tem como principal característica o fluxo e a fluidez existem no estuário áreas de "remanso", ou seja, em que a água está "parada", conforme afirmou o PA3 (42 anos). Corroborando o entendimento do pescador sobre o remanso, Guerra (1993) explica que este se trata de um trecho de um rio no qual a corrente fluvial fica estagnada.

\section{OS PROCESSOS GEOMORFOLÓGICOS EROSIVOS E DEPOSICIONAIS}

No que concerne especificamente aos processos geomorfológicos modeladores dos ambientes estuarinos e costeiros, são observados pelos pescadores os processos de erosão e deposição como determinantes na progradação e retrogradação da linha de costa. A hidrodinâmica possui um papel central para a modelagem costeira, atuando na configuração geomorfológica tanto num perfil vertical, com os sistemas de barra/canal, como horizontal, como na formação das praias e feições estuarinas.

Os pescadores reconhecem o mar como nível de base local, como contido implicitamente na seguinte fala: "toda a água que bater aqui em cima só vai descer para baixo, para a maré (mar)"(PSL3, 49 anos).

As marés são entendidas como os principais agentes geomorfológicos da paisagem costeira e estuarina, de modo que a maré grande (maré de sizígia) "come", ou seja, erode e a maré morta (quadratura) "bota", ou seja, deposita sedimentos. O PCV6 (41 anos) também destaca o papel das ondas na modelagem geomorfológica costeira quando afirma que "a onda agitada ela cava (...) quando a onda bate faz um buraco" e explica que posteriormente as marés trazem os sedimentos novamente, recobrindo estes buracos.

Ainda segundo este pescador existe meses específicos em que a "maré cava mais", isto é, ocorre maior atuação dos processos erosivos. Esses meses são geralmente àqueles de maior atuação dos ventos e precipitações (período denominado localmente de inverno), pois o vento é visto como um importante agente geomorfológico, o qual é responsável pela entrada e saída de sedimentos em determinado espaço, dada a sua influência direta sobre a hidrodinâmica local.

Os pescadores observam que nas áreas de "beira da praia" ocorre a retirada de sedimentos, pois "o mar tá avançando, tá retomando o que é dele" e isso está ocorrendo porque "aterraram o mangue, fizeram casa na beira do mar, a população tá crescendo (sobretudo nas áreas litorâneas, e isso implica na expansão urbana e consequentes impactos ambientais)" (PSL9, 35 anos). Outro pescador afirma que:

O mar vem avançando (...) há anos atrás tinha casa aqui, sabe? Essa área desse barco aí tinha casa (...) aí muitas casas que ficam na beira da praia, aí alguém pensa que o homem tá invadindo, mas é por causa do avanço do mar (PBC7, 45 anos).

No entanto, acentuando a responsabilidade humana acerca do avanço marinho, uma pescadora destaca que "o mar não cresceu, foi a invasão que teve lá fora", enfatizando que o problema está na ocupação de áreas impróprias: 
As pessoas é que fica invadindo a beira-mar (...) o mar vai correr para outro canto, mas depois o mar vai dar retorno (...) Aí o mar tá avançando é? Não! Eu que tomei, eu tenho que ter é consciência. Não é que o mar tomou, não é que avançou, o pessoal que tão fazendo as coisa que não é pra fazer, porque acha que tem dinheiro, acha que pode. Ninguém na Terra não pode nada não, só quem pode é Deus! (PBC1, 43 anos).

Destarte, a ação antrópica é tida como a principal desencadeadora do processo erosivo e do "avanço do mar" relatado, destacando-se, sobretudo, ações como o desmatamento, aterros e ocupação de áreas impróprias como os manguezais.

Alguns pescadores como o PA7 (48 anos) também enfatizam o papel do aquecimento global e o derretimento das calotas polares: "o oceano dos gelo que vem derretendo aí o mar avança (...) o gelo se desmancha ai o mar sobe sempre, ai sobe essa maré alta, na praia o mar é brabo".

Além disso, os pescadores denotam uma visão ambiental integrada ${ }^{6}$ e compreensão da amplitude espacial acerca das ações antrópicas e impactos ambientais associados, quando afirmam, como o PBC8 (71 anos) que "aterra lá e prejudica nóis aqui" e "os efeitos do que acontece num lugar chega em outro pelas correntes marítimas (...) porque tão destruindo tudo, por causa da ação humana, toda destruição parte do homem" (PSL6, 36 anos).

A dinamicidade da faixa costeira percebida através da constante troca de matéria e energia tem causado processos erosivos e demandado a construção de estruturas de proteção costeira, as "espias" (Figuras 5 e 6), correspondentes aos espigões e definidos pelos pescadores como "paredões de pedra". São as principais estruturas construídas na comunidade Carne de Vaca para conter os processos erosivos que são claramente observados na localidade.

No entanto, apesar das medidas infraestruturais, os pescadores destacam que algumas formas naturais também exercem proteção costeira, tais como a "Pedra da Galé"7 e também as ilhas e barras arenosas. A comunidade de Atapuz, por exemplo, que foi construída sobre uma área de aterro de manguezal, não sofre acentuadamente com a força da ação marinha por causa da presença da llha de Itamaracá e de Barra de Catuama, que são formas naturais que protegem essa área, relatam os entrevistados.

\footnotetext{
6 Souto (2004) também observou a visão holística dos pescadores artesanais de Acupe através do entendimento da interdependência existente entre integrantes bióticos e entre estes e fatores abióticos. Toledo (2001) afirma que o conhecimento dos povos e comunidades tradicionais é holístico porque está intrinsecamente ligado às necessidades de uso e manejo dos recursos naturais, não se restringindo aos aspectos estruturais da natureza (etno- taxonomia), mas englobando também aspectos dinâmicos, relacionais e de dimensões utilitárias dos recursos naturais.

${ }^{7} \mathrm{O}$ termo Pedra da Galé é usado localmente para denominar os recifes/beachrocks e é descrito como "uma pedra que nasceu no meio do mar" e que "roda o mundo", "que em determinados locais ela aparece mais para fora ou para dentro" (próxima ou mais afastada da costa).
} 
Figura 5: "Espias", estruturas de proteção contra a erosão costeira na praia Carne de Vaca. Em A, observa-se a espia com acúmulo de sedimentos pós-estrutura; em $B$ observa-se a reentrância e erosão a sotamar da obra, resultado de mudanças na dinâmica hidrológica e sedimentar local, provocadas pela construção das espias.
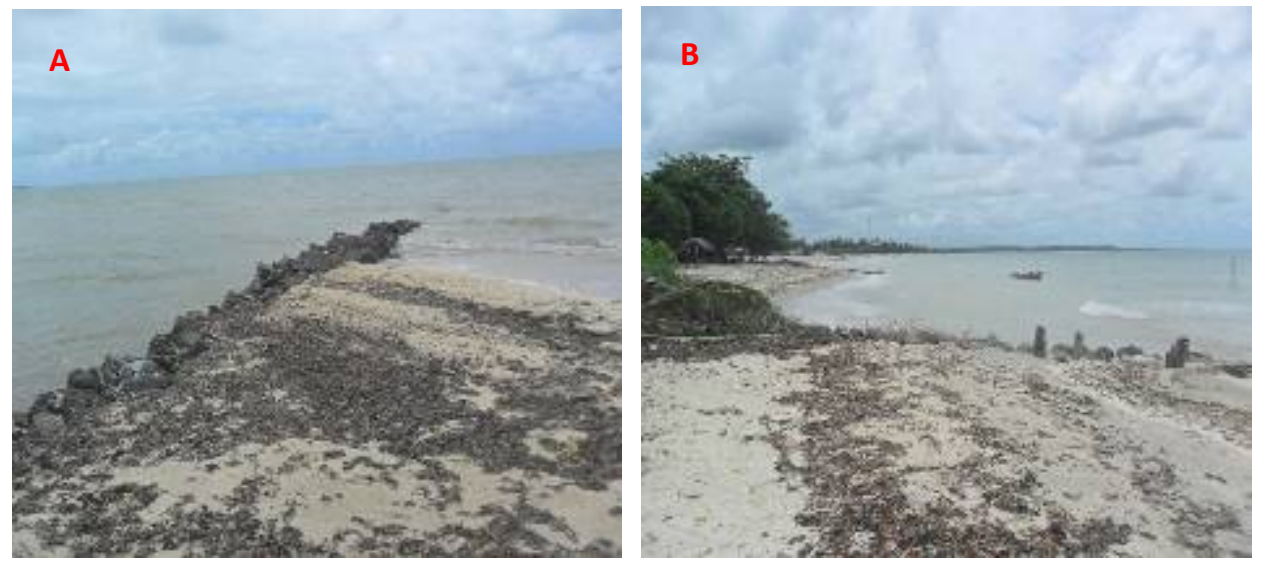

Fonte: Autores. Trabalho de campo realizado em 01/04/2016.

Figura 6: Processos erosivos em Carne de Vaca. Na imagem do Google Earth podemos observar o papel das espias no acúmulo sedimentar. No entanto, essas estruturas desencadeiam processos erosivos à jusante delas. Nas fotos, erosão no trecho norte da referida praia, onde podemos ver o alicerce de uma casa e as raízes dos coqueiros expostos pela retirada de sedimentos. Além disso, é possível notar o quão próximo às edificações se encontram do mar.

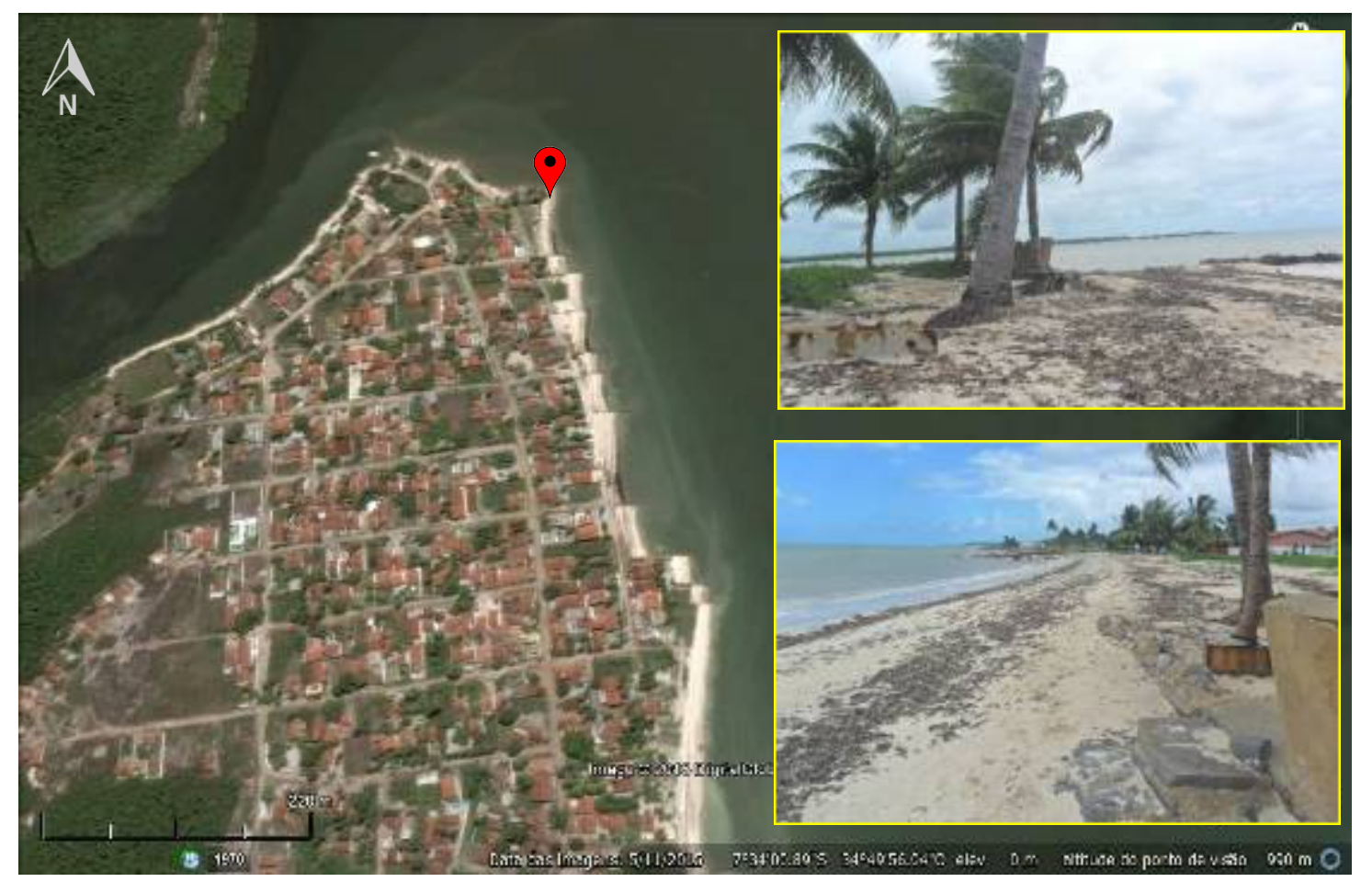

Fonte: Google Earth (2016) e autores. Trabalho de campo realizado em 01/04/2016. 
Os pescadores têm consciência das mudanças na dinâmica sedimentar local a partir da intervenção com estruturas de proteção costeira como as "espias", como afirma o PCV2 (64 anos): "se o governo fizer espia só lá em Canoé (porção a sotamar, já no estado da Paraíba), aqui junta mais terra". Outros pescadores relatam que com as "espias" a tendência é só juntar terra". Assim sendo, há de se considerar que a construção de estruturas desse tipo desencadeia acreção de sedimentos a barlamar e erosão a sotamar do local onde estão instaladas (Figuras 5 e 6).

Além da dinâmica sedimentar no plano horizontal, os pescadores também reconhecem essa dinâmica no plano vertical, através do sistema de barras e canais. Neste sentido, o PCV3 (76 anos) afirma que "entra muita areia nessa barra e acaba com a fundura do canal", descrevendo a dinamicidade sedimentar dessas formas submersas.

Apesar das variações no nível do mar serem vistas como fenômenos naturais, reconhecem que a ação humana tem interferido de maneira negativa. Entretanto, o mar é visto como um elemento dotado de imponência, que reivindica o seu espaço, dentro de uma perspectiva sistêmica e cíclica, "onde o mar bota, onde é dele, ele sempre voltará" (PCV6, 41 anos) porque "a natureza ninguém brinca com ela não" (PCV1, 50 anos).

A respeito de um aumento nos processos deposicionais, em Barra de Catuama os pescadores relatam estar havendo acentuada deposição sedimentar que ocorre por causa do "vento gerá" (vento forte que vem do mar), das correntezas e das invasões em áreas impróprias nas regiões costeiras. O PBC2 (29 anos) complementa que está havendo um "recuamento da areia do mar que tá indo para a costa (...) e a areia do mar, ela mata o mangue porque a folha que cai do mangue é que utiliza e faz a geração de lama, e a areia vem e destrói, acaba com tudo..." e conclui: "o que era mangue é areia hoje, a maré dá e toma".

Segundo os pescadores dessa comunidade, o resultado desse processo deposicional acentuado está sendo o soterramento de áreas de manguezal. Ao observar a Figura 7, e identificar a expressividade das formas arenosas, vemos uma possível evidência que pode ratificar as afirmações dos entrevistados. Tal fato pode estar associado além do fato da comunidade estar localizada em área de desembocadura fluvial, local de grande aporte sedimentar; em virtude das estruturas de proteção costeira instaladas nas comunidades a sotamar, como em Carne de Vaca, que ocasionam o "aprisionamento" de sedimentos nessa área.

De maneira geral, os avanços e recuos marinhos destacados na fala dos pescadores podem estar associados a ciclos deposicionais e erosivos, decorrentes de alterações nos fluxos hidrodinâmico e sedimentar por conta da ação antrópica. Manso et al. (2006 apud ANDRADE, 2013) destacam, por exemplo, que os 35 molhes instalados nas praias no município de Olinda, alterou significativamente a circulação de sedimentos na área, transferindo a ação erosiva a sotamar, até o trecho da llha de Itamaracá (área a barlamar da presente área de estudo).

Manso et al. (2006) também abordam que as mudanças constantes da configuração batimétrica da plataforma continental interna adjacente alteram 0 mecanismo de sedimentação das praias, e podem provocar a erosão na linha de costa, como ocorre na praia de Itamaracá. Segundo eles, nessa área em um período de aproximadamente 40 anos, toda a areia da praia se transferiu para a plataforma adjacente cobrindo o substrato lamoso e criando bancos arenosos (formas expressivas nas comunidades analisadas). 
Figura 7: Vista aérea de Barra de Catuama. Observa-se as barras arenosas na desembocadura do canal de Santa Cruz. À direita, ilha de Itapessoca; no extremo noroeste, Ilha de Itamaracá; e ao fundo, no extremo nordeste, a comunidade de Atapuz. As flechas em amarelo destacam as formas denominadas pelos pescadores de "croa".

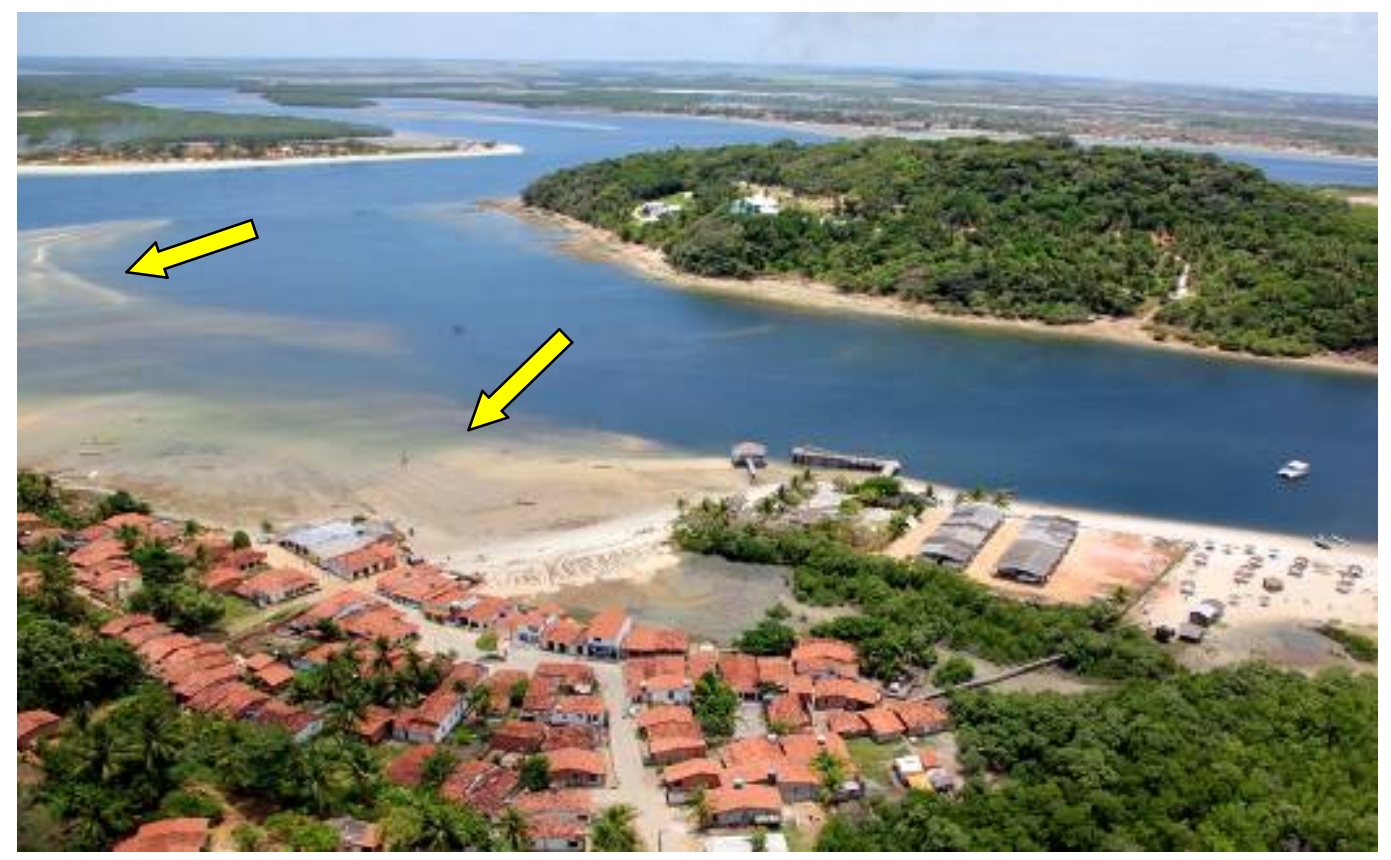

Fonte: Blog do Tenente Menezes

(Acesso em 29/12/2016).

Quanto aos manguezais, estes possuem uma série de funções ambientais de suma importância como: a preservação da linha de costa, retenção de sedimentos, filtro biológico e berçário (DIEGUES, 1991 apud SCHAEFFER-NOVELLI, 2008) e essas funções são reconhecidas pelos pescadores artesanais. Destacamos o reconhecimento do papel geomorfológico do manguezal como zona amortecedora da área costeira, quando dizem que a "maré não avança na gente por causa desses mangue ai" (PA1, 28 anos) e "se cortar o mangue o mar vem bater aquil" (PA9, 53 anos).

As estações do ano as quais definem períodos de maior ou menor precipitação, também são vistas como influentes na intensidade de atuação dos processos geomorfológicos e do perfil sedimentológico predominante, pois há tempos em que o mar "come" (erode) a areia e leva os sedimentos para outros locais. Segundo eles, nas "marés de inverno" (marés que ocorrem no período de maior precipitação) sedimentos finos recobrem os arenosos, e na "maré de verão" (que ocorre nos períodos de menor precipitação) os sedimentos arenosos são prevalecentes. Esses períodos também são vistos como influentes na dinâmica das formas geomorfológicas como as "croas", pois "quando chove muito a água tem carregado a areia para dentro do rio (por causa do maior aporte de sedimentos) e forma croa" (PSL7, 56 anos). 
Já o assoreamento do canal fluvial estuarino foi destacado como desencadeado por atividades antrópicas tais como: construções de estradas ribeirinhas, monocultura de cana de açúcar e implantação da carcinicultura, que em sua fase inicial demandou revolvimento de terras. Dois pescadores relatam 0 problema: "a água trouxe terra aterrando o rio, deixando o rio raso" (PSL5, 67 anos) e "a água do canavial, das construções das estradas, tudo vai para o rio e a água fica suja" (PSL9, 35 anos). Contudo, além destes fatores antrópicos, há de se destacar a natural deposição sedimentar nos ambientes estuarinos, como zona terminal da fluidez do canal fluvial.

\section{CONCLUSÃO}

Ao observar a percepção dos pescadores artesanais do litoral de Goiana- PE acerca dos processos modeladores da paisagem costeira e estuarina local constatase que estes conseguem realizar uma inter-relação entre os processos de ordem hidrodinâmica e os de ordem geomorfológica, compreendendo que há uma interdependência entre ambos para a evolução processual da dinâmica de tal ambiente.

A atividade pesqueira requer um apurado reconhecimento das condições físico-naturais locais, sendo esta a causa dos pescadores reconhecerem a influência dos processos hidrodinâmicos sobre a pesca, já que o regime das marés e a atuação das correntes costeiras refletem diretamente no comportamento das espécies explotadas, tanto na atividade de pesca quanto no extrativismo animal.

Um aspecto relevante observado neste estudo foi a visão de natureza integrada que os entrevistados demonstraram possuir, pois o pescador tem uma visão dentro de uma perspectiva ambiental sistêmica onde cada componente ambiental possui influência sobre o todo, de modo que a alteração em um componente do sistema causa distúrbios em sua dimensão total. Tais alterações de maneira geral são entendidas como provindas da ação antrópica, a qual é enfatizada na origem de problemas ambientais observados na zona costeira como a intensificação de processos erosivos em determinados pontos do litoral.

Além da noção de paisagem integrada, o pescador artesanal vê a paisagem dentro de uma perspectiva dinâmica, pois compreendem que esta está sendo constantemente remodelada por dinâmicas marinhas, continentais e atmosféricas. Entendem que a dinamicidade nos aspectos fisionômicos da paisagem é comandada pela atuação de processos que atuam tanto dentro de uma perspectiva sazonal como de longo prazo. A percepção do papel dos processos sobre a configuração das formas, definindo a sua fisionomia e dinâmica é constatada recorrentemente em depoimentos.

Destaca-se que o conhecimento retido pelos pescadores artesanais foi construído através da apropriação da natureza, como um pré-requisito básico para a efetuação da atividade pesqueira. Tendo a vida ditada pela dinâmica da natureza, aprenderam a interpretá-la, traduzindo os seus segredos, e edificando um importante acervo de conhecimentos ambientais, que são a principal ferramenta para a sua sobrevivência e resistência sociocultural.

Tal como Ashmore (2015) e Gregory (2006), destaca-se o valor do conhecimento local e a necessidade de sua inclusão nas ações de planejamento e gestão ambiental e territorial, revelando a importância da etnogeomorfologia enquanto uma abordagem que pode contribuir não somente para a popularização dos conhecimentos geomorfológicos, mas também para o reconhecimento da 
relação do pescador com o ambiente. Tal relação, que se efetiva tendo como elo a atividade pesqueira, pode propiciar a adequabilidade e melhor execução de projetos ambientais e de ordenamento territorial de intervenção local, que levem em consideração não somente a dinâmica (etno) geomorfológica e (etno) ecológica, muito bem conhecida por eles, mas também os valores, conhecimentos e práticas socioculturais locais que a longo prazo vem mantendo um necessário equilíbrio ao ambiente costeiro.

\section{REFERÊNCIAS}

ALCANTARA, V. C.; TORRES, F. S. M.; LIMA, E. A. M. Evolução Geológica. In: TORRES, F. S. M.; PFALTZGRAFF, P. A. S. (org.). Geodiversidade do estado de Pernambuco. Recife: CPRM, 2014. p. 15-32.

ALLUT, A. G. O Conhecimento dos especialistas e seu papel no desenho de novas políticas pesqueiras. In: DIEGUES, A. C. (org.). Etnoconservação: novos rumos para a conservação da natureza. 2. ed. São Paulo: NUPAUB-USP, 2000. p. 101123.

ALMEIDA, L. G. D. Caracterização das áreas de pesca artesanal de lagosta na Praia da Redonda, Icapuí- CE. 2010. Dissertação de Mestrado em Ciências Marinhas Tropicais apresentada à Universidade Federal do Ceará (UFC-CE, Brasil).

ALVES, R. R. N.; NISHIDA, A. K. A Ecdise do Caranguejo- Uçá, Ucides Cordatus L. (Decapoda, Brachyura) na visão dos caranguejeiros. Interciência, v. 27, n. 3, p. 110117, 2002.

ANDRADE, C. D. P. Áreas potenciais a exploração de granulados marinhos siliclásticos para a recuperação artificial de praias na plataforma continental interna adjacente ao Porto de Recife- PE. 2013. Dissertação de Mestrado em Geociências apresentada à Universidade Federal do Rio Grande do Sul (UFRS- RS, Brasil).

ASHMORE, P. Towards a sociogeomorphology of rivers, Geomorphology, p 01-08, 2015. Disponível em: http://dx.doi.org/10.1016/j.geomorph.2015.02.020 Acesso em: 27 de maio de 2016.

ASSOCIAÇÃO PORTUGUESA DOS RECURSOS HIDRICOS - APRH. Glossário de Gestão Costeira Integrada. 2007. Disponível em: http://www.aprh.pt/rgci/glossario/index.html

ASSIS, H. M. B. Influência da hidrodinâmica das ondas no zoneamento litorâneo e na faixa costeira emersa, entre Olinda e Porto de Galinhas, Pernambuco. 2007. Tese de Doutorado em Geociências apresentada à Universidade Federal de Pernambuco (UFPE- PE, Brasil).

BARBOSA, J. L. P. Hidromorfologias e hidroformas costeiras locais. 2007. Tese de Doutorado apresentada à Faculdade de Engenharia da Universidade do Porto (Portugal).

BARBOSA, J. A.; LIMA FILHO, M. Os Domínios da Bacia da Paraíba. In: CONGRESSO BRASILEIRO DE P\&D EM PETRÓLEO E GÁS, 3., Salvador, 2005. Anais... Salvador: [s.n.], 2005. 
BARRERA-BASSOLS, N.; TOLEDO, V. M. Ethnoecology of the Yucatec Maya: Symbolism, Knowledge and Management of Natural Resources. Journal of Latin American Geography, v.4, n.1, p. 9- 41, 2005.

BARRERA-BASSOLS, N.; ZINCK, J. A. Ethnopedology: a worldwide view on the soil knowledge of local people, Geoderma, v. 111, n.3, p. 171-195, 2003.

BIRD, E. C. F. Coastal geomorphology: an introduction. 2 ed. Chichester John Wiley \& Sons, 2008.

BLOG DO TENENTE MENEZES. Paradisíaco Litoral de Goiana- PE. 2011. Disponível em: http://blogdotenentemenezes.blogspot.com.br/2011/07/paradisiacolitoral-de-goiana-pe.html Acesso em: 29 de dez. de 2016.

CABRAL, L. O. A paisagem enquanto fenômeno vivido. Geosul, Florianópolis, v.15, n. 30, p 34-45, jul./dez. 2000.

CALLIARI, L. J.; MUEHE, D., HOEFEL, F. G.; TOLDO JR., E. Morfodinâmica praial: uma breve revisão. Revista Brasileira de Oceanografia, v. 5I, n. único, p. 63-78, 2003.

CARDOSO, E. S. Pescadores Artesanais: natureza, território, movimento social. 2001. Tese de Doutorado em Geografia Física apresentada à Universidade de São Paulo (USP-SP, Brasil).

CENTRO DE ESTUDOS DO MAR - CEM/UFPR. Correntes geradas por ondas. Disponível em: http://www.cem.ufpr.br/praia/pagina/pagina.php?menu=correntes Acesso em: 30 de jul. de 2016.

COMPANHIA PERNAMBUCANA DO MEIO AMBIENTE-CPRH. Diagnóstico socioambiental do Litoral Norte de Pernambuco. CPRH: Recife, 2003. 214p.

DIEGUES, A. C. S. O mito moderno da natureza intocada. São Paulo: HUCITEC, 1996.

GARCEZ, D. S. Caracterização da pesca artesanal autônoma em distintos compartimentos fisiográficos e suas áreas de influência, no estado do Rio de Janeiro. 2007. Tese de Doutorado em Geografia apresentada à Universidade Federal do Rio de Janeiro (UFRJ- RJ, Brasil) Rio de Janeiro, 2007.

GOOGLE EARTH. Acesso em: 29 de novembro de 2016.

GREGORY, K. J. The human role in changing river channels. Geomorphology, v.79, n. 3, p. 172-191, 2006.

GUERRA, A. T. Dicionário geológico-geomorfológico. 8. ed. Rio de Janeiro: IBGE, 1993.

INSTITUTO HIDROGRÁFICO. Marinha-Portugal. Disponível em: http://www.hidrografico.pt/ Acesso em: 24 de nov. de 2016.

LESSA, Rosangela, et al. "Diagnóstico da pesca no litoral do estado de Pernambuco." A pesca marinha e estuarina do Brasil no início do século XXI: recursos, tecnologias, aspectos socioeconômicos e institucionais. Editora da Universidade Federal do Pará, Belém, 2006, p. 67-91.

LIRA, L. et al. Estudo de correntes marinhas por meio do lançamento de cartões de deriva no litoral do estado de Pernambuco, Brasil. Arquivos de Ciências do Mar, Fortaleza, v. 43, n. 1, p. $30-37,2010$. 
MANSO, V. A. V.; COUTINHO, P. N.; GUERRA, N. C.; JUNIOR, C. F. A. S. Erosão e Progradação do Litoral Brasileiro/Pernambuco. In: MUEHE, D. Erosão e Progradação do Litoral Brasileiro. Brasília: MMA, 2006. p.179-196.

MARINS, R. V. (org.). Glossário de oceanografia abiótica. Fortaleza: UFC/LABOMAR/NAVE, 2010. 138p.

MORETZ-SOHN, C. D. et al. Pescadores artesanais e a implementação de áreas marinhas protegidas: Estudo de caso no nordeste do Brasil. Revista de Gestão Costeira Integrada, v. 13, n.2, p. p. 193-204, 2013.

PEDROSA, R. A. Pesca, perfil socioeconômico e percepção ecológica dos pescadores artesanais de Porto de Galinhas, PE. 2007. Dissertação de Mestrado em Oceanografia apresentada à Universidade Federal de Pernambuco (UFPE-PE, Brasil).

PÊSSOA, V. L. S. Geografia e pesquisa qualitativa: um olhar sobre o processo investigativo. Geo/ UERJ, v. 1, ano 14, n. 23, p. 4-18, 2012. Disponível em:http://www.e-publicacoes.uerj.br/index.php/geouerj Acesso em 8 de jun. de 2015.

PORTOGENTE. Mar cavado. Disponível em: https://portogente.com.br/portopedia/76926-mar-cavado Acesso em: 14 de out. de 2016.

RAMALHO, C. O mundo das águas e seus laços de pertencimento. Raízes, Campina Grande, v. 23, n. 01-02, p. 62-72, jan./dez. 2004.

RIBEIRO, S. C. Etnogeomorfologia sertaneja: proposta metodológica para a classificação das paisagens da sub-bacia do rio Salgado/CE. 2012. Tese de Doutorado em Geografia apresentada à Universidade Federal do Rio de Janeiro (UFRJ-RJ, Brasil).

SALDANHA, I. R. R. Espaços, recursos e conhecimento tradicional dos pescadores de manjuba (Anchoviella lepidentostole) em Iguape / SP. 2005. Dissertação de Mestrado apresentada à Universidade de São Paulo (USP-SP, Brasil).

SANTOS, J. L.O que é cultura. São Paulo: Brasiliense, 2006.

SCHAEFFER-NOVELLI, Y. Situação atual do grupo de ecossistemas: manguezal, marisma e apicum, incluindo os principais vetores de pressão e as perspectivas para sua conservação e usos sustentável. Brasília: Agência Nacional de Petróleo, Gás Natural e Biocombustíveis, 2008.

SECRETARIA ESPECIAL DE AQUICULTURA E PESCA DA PRESIDÊNCIA DA REPÚBLICA- SEAP. Instrução Normativa Nº 03, 12 de maio de 2004.

SILVA, F. B. R., et al., Zoneamento Agroecológico do Estado de Pernambuco. Recife, Embrapa Solos/Governo do Estado de Pernambuco- Secretaria de Produção Rural e Reforma Agrária. CD-ROM, 2001.

SILVA, J. B.; GALVÍNCIO, J. D.; CORREAA, A. C. B.; SILVA, D. G.; MACHADO, C. C. C. Classificação Geomorfológica dos Estuários do Estado de Pernambuco (Brasil) com Base em Imagens do LANDSAT 5/TM. Revista Brasileira de Geografia Física, v. 01, p. 118-133, 2011. 
SILVA, J. B. Territorialidade da Pesca no Estuário de Itapessoca-PE: técnicas, petrechos, espécies e impactos ambientais. 2006. 83f. Dissertação de Mestrado apresentada à Universidade Federal de Pernambuco (UFPE-PE, Brasil).

SILVA, S. M.; GARCÍA, M. F. O mar está pra peixe? Trabalho e natureza na pesca artesanal em Lucena, Brasil. SEMATA, Ciências Sociais e Humanidades, v. 25, p. 179-204, 2013.

SOUTO, Francisco José Bezerra. A ciência que veio da lama: uma abordagem etnoecológica abrangente das relações ser humano/manguezal na comunidade pesqueira de Acupe, Santo Amaro, Bahia. 2004. Tese de Doutorado apresentada à Universidade Federal de São Carlos (UFSCar-SP, Brasil).

TOLEDO, V. M.; BARRERA-BASSOLS, N. A Etnoecologia: uma ciência pós-normal que estuda as sabedorias tradicionais. Desenvolvimento e Meio Ambiente, n.20, p.31-45, jul./dez. 2009.

TOLEDO, VICTOR M. "Povos/comunidades tradicionais e a biodiversidade." Encyclopedia of Biodiversity, p. 451-463, 2001.

WILCOCK, D.; BRIERLEY, G.; HOWITT, R. Ethnogeomorphology. Progress in Physical Geography, p. 1-28, 2013

WILCOCK, D.A. Living Landscapes: 'Ethnogeomorphology' as an ethical frame of communication in environmental decision-making. 2011. Tese de Doutorado em Filosofia apresentada à York University (UK)

WINGE, M. et al. Glossário Geológico Ilustrado. 2001. Disponível em: http://sigep.cprm.gov.br/glossario/index.html Acesso em 13 de dez. de 2016 